\title{
District-level Urban Governance Policies in India: Cities of Neglect?
}

\author{
Anil Kumar Vaddiraju \\ Institute for Social and Economic Change
}

This article deals with urban governance policy and planning with respect to two Indian states, Karnataka and Telangana, at the district level. While there is a clearly envisioned policy for urban governance in India, this article highlights that its implementation continues to remain incomplete. The article examines whether the constitutional provisions envisaged for the said purposes are being practised or not. In the process, demonstrates that while the provision of drinking water and sanitation remains a problem across the cities discussed, social capital in terms of making governance work and cope with communal issues too is a major issue.

Keywords: India, urban governance, district level, $74^{\text {th }}$ Amendment, Karnataka, Telangana, social capital, urban planning, sanitation, drinking water

\section{INTRODUCTION}

This article deals with urban governance policy and planning with reference to two Indian states at the district level. It examines whether the provisions envisaged under the constitution for the said purposes are being practised, and if so, how these practices take place within a larger state-level policy context. This article primarily raises four questions concerning the three district cities of two states, namely Karnataka and Telangana. The questions are: a) how is the district city planning taking place?; b) How effective/ efficient is the delivery of basic services such as drinking water and sanitation?; c) How effective is the city governance?; and d) lastly, are there any social capital issues that merit attention?

This article argues that the major reason for an apparent governance deficit at this level is the lack of social capital a) in making the government work towards providing basic civic amenities such as sanitation and drinking water, and b) in improving inter-ethnic relations. We define social capital basically as increased cooperation between political parties and among citizens connoting inter-ethnic relations. Therefore, given a constitutional structure with well defined responsibilities, city-level governance as well as inter-ethnic relations can improve considerably in the presence of increased social capital. It is important to note that the state of governance delivery in most of the district-level cities points to the relevance of social capital in city governance in terms of providing basic civic services in running the city administration. By social capital, we mean trust, reciprocity and norms among citizens reflected in the city governance. Social capital is important for these cities in order to maintain cordial relations between different religious communities, and more importantly, to deliver a proper city governance. While the relevance of social capital to promoting the inter-ethnic relations is a complex issue, it is important when it comes to a smooth delivery of essential minimum services, such as drinking water, sanitation and solid waste management. Further, where social capital and citizen action are actively 
present, city governments are kept on their toes and in their absence, city governance suffers. However, the reader may well be reminded that the question of social capital figures last among the four questions raised in the beginning and not the central question this paper focuses on. It is only that the paper also dwells on social capital; the three questions raised in the beginning respectively form the central foci of this paper.

We follow the approach of comparing two states as part of studying political phenomena, as shown by Jenkins (2004). The article focuses on two states, Karnataka and Telangana ${ }^{1}$, and three district cities, namely, Udupi and Dharwad in Karnataka, and Mahabubnagar ${ }^{2}$ in Telangana. As part of methodology, the study relies on interviews with key informants in all the three cities in both the states. These include key political figures, local bureaucracy, academics, journalists, prominent citizens and observers of these cities. The article is thus based on primary research in respect of these cities.

This paper is divided into five sections: the following section deals with the nature of urbanization in the above said states and the neglect of district level urban governance; the second section deals with urban decentralized planning and its status; the third section focuses on Karnataka and consists of case studies of Dharwad and Udupi; the fourth section focuses on Telangana and consists of Mahabubnagar case study. The fifth section draws all the strands together.

\section{NEGLECT OF THE DISTRICT LEVEL URBAN GOVERNANCE}

Among all the urban studies sub-disciplines, urban governance is the most neglected. This is even more so in the context of district-level cities. Often in urban research, big cities hog the limelight while relegating smaller cities to academic margins. The macro-policy related to urban governance is to be guided by the $74^{\text {th }}$ Constitutional Amendment, but in implementation, the policy remains highly neglected. This is particularly so at the district-level cities. Here, bureaucracy takes all the decisions. In Karnataka, it is the District Collector (DC) office that determines all the governance related issues (Anil Kumar:2013), while in Telangana, it is the Municipal Commissioner office that takes all the decisions. Hence, in the district-level cities, the attention paid to governance is minimal, because the responsibilities of these officials are far too many for them to pay attention to city governance.

Local governments in these cities are often weak, and the powers devolved to them and the resources they have are also limited (Swain: 2013). These shortcomings are becoming more visible at a time when economic growth is rapid with the private sector expanding into these cities at a rapid pace (Shaw: 2013). The local governance at the district-level cities is woefully inadequate as compared to their economic growth. As a result, these cities are becoming chaotic with basic civic services such as sanitation, drinking water and solid waste management being neglected or overlooked often.

District-level towns often find themselves neglected in terms of governance, and this is the state of affairs throughout the country. The main reason for this lies in the policy bias shown by the successive governments towards mega urban centres and agglomerations with the entire attention being directed towards mega cities. In policy enunciation, practice and academic research, a sufficient attention has not been paid to district-level towns (Gill:2013). Central and state governments have been changing periodically, but the policy towards these towns has not undergone any major transformation.

Across the overall urbanization scenario of the country, the South Indian states are quite ahead, along with Maharashtra, Gujarat, Punjab and Goa. The urbanization process has expanded rapidly in South India. In Kerala, urbanization constitutes 47.72 percent; in Tamil Nadu it is 48.45 percent; in Karnataka 38.57; and in Andhra Pradesh (united) 33.49 percent. Urbanization in all the above states together remains above the national average of 31.2 percent

As far as Karnataka is concerned, what is worrisome is the nature and pattern of urbanization in that the urbanization process continues to remain spatially skewed towards one metropolitan city, that is, Bangalore, resulting in serious urban governance and management problems. Urbanization of this nature defies spatial justice, and as such, causes problems of migration, and difficulties in providing housing, civic amenities, law and order and a myriad other services, particularly at a time when urban population is growing at a faster pace than rural population, as is the case with Karnataka.

Journal of Leadership, Accountability and Ethics Vol. 17(4) 2020115 
We emphasise this because as much as 67 percent of the urban population in the state of Karnataka is concentrated in 24 class-I cities, while the remaining 33 percent is spread across other cities and towns, whose total number stand at 237. Of these, the largest number of 101 is in Class-III category, consisting of only 17 percent of the urban population. A striking feature of this pattern of urbanization is that Bangalore alone accounts for 30 percent of the total urban population of the state. Bangalore is what urbanization studies call a 'primate city', that is, the biggest city in the state which is nine times bigger than the next major urban conglomeration, Hubli- Dharwad. ${ }^{3}$

While we have these data for Karnataka, there are no comparative statistics available for Telangana. Therefore, while it is difficult to provide a statistical profile of urbanization in respect of Telangana, our primary research shows that Hyderabad occupies the same place as Bangalore in Karnataka, a 'primate city'. Hyderabad is the biggest city in Telangana and the attention paid by various governments towards Hyderabad has not been matched by a similar level of attention to other cities/towns of Telangana.

The general argument advanced with respect to economies of scale and agglomeration benefits does not apply to such mega-cities. Instead, such a spatially-skewed urbanization benefits the elites, resulting in housing and real estate prices sky-rocketing and city governance suffering. As a consequence of such growth, many extra-legal groups seek to benefit from the city's development. Rent-seeking too afflicts city governance. One more consequence of such development is that all the attention of the state government shifts to larger cities at the expense of governance of the rest of the cities. This is quite clear in respect of Karnataka and Telangana.

In this pattern of urbanization, the governance of cities that are at the district and lower levels, becomes hugely problematic. Often the metropolitan and district planning committees are not constituted, and if constituted, their functioning is minimal vis-à-vis urban governance. In such circumstances, the governance of urban local bodies shifts from constitutionally-elected functionaries to the state government and its bureaucracy, as many of the functions and responsibilities are controlled by the state government and its line departments.

\section{MACRO NATIONAL POLICY}

A macro-policy for urban governance at the district-level is provided by the $74^{\text {th }}$ Constitutional Amendment. The main features of this are: conducting regular periodic elections with an affirmative action for SCs, STs and OBCs; providing 33 percent reservation for women; planning for the town/city through district planning committees; planning for the metropolitan cities through Metropolitan Planning Committees; and constituting ward committees for citizen participation in governance

Regarding planning, the Constitution, as per article 243ZD (Jha and Mathur, 1996), has this to say:

1. There shall be constituted in every state at the district level a district planning committee to consolidate the plans provided by the panchayats and the municipalities in the district and to prepare a draft development plan for the district as a whole.

2. The legislature of a state may, by law, may make provisions with respect to

a) The composition of the district planning committees

b) The manner in which the seats in such committees shall be filled.

Provided that not less than four-fifths of the total number of members of such committee shall be elected by, and from amongst, the elected members of panchayat at the district level and of the municipalities in the district in proportion to the ratio between population of the rural areas and of the urban areas in the district;

c) The functions relating to district planning which may be assigned to such committees;

d) The manner in which the chairperson of such committees shall be chosen'

According to the Twelfth Schedule of the Constitution, i.e., article 243W, eighteen aspects of governance are to be devolved to urban local bodies (Jha and Mathur:1996). Therefore, the macro-policy 
towards district urban planning and governance is clear. The Constitution is also clear on the devolution of powers and the functions are to be devolved to the local bodies. However, while the $74^{\text {th }}$ Amendment to the constitution was promulgated by the central legislature, powers to the local bodies are to be devolved by state governments in India. In this respect, both Karnataka and Telangana have fared equally poorly.

TABLE 1

A BASIC PROFILE OF THE THREE DISTRICT CITIES

\begin{tabular}{|l|l|l|l|l|l|l|l|}
\hline & $\begin{array}{l}\text { Total } \\
\text { Population }\end{array}$ & Male & Female & $\begin{array}{l}\text { Total } \\
\text { Literates }\end{array}$ & $\begin{array}{l}\text { Male } \\
\text { Literates }\end{array}$ & $\begin{array}{l}\text { Female } \\
\text { Literates }\end{array}$ & $\begin{array}{l}\text { Average } \\
\text { Literacy } \\
(\%)\end{array}$ \\
\hline Udupi & $1,44,960$ & 71,614 & 73,346 & $1,07,302$ & 54,175 & 53,127 & 93.55 \\
\hline $\begin{array}{l}\text { Hubballi- } \\
\text { Dharwad }\end{array}$ & $9,43,788$ & $4,74,518$ & $4,69,270$ & $7,27,103$ & $3,82,913$ & $3,44,190$ & 86.7 \\
\hline Mahabubnagar & $2,10,258$ & $1,06,086$ & $1,04,172$ & $1,52,477$ & 82,790 & 68,687 & 81.88 \\
\hline
\end{tabular}

Source: 2011 Census of India

\section{Urban Governance Policy in Karnataka}

Although the $74^{\text {th }}$ amendment to the Constitution stipulates several provisions to be followed with respect to governance, the situation in Karnataka appears to be different. Two quotations presented below make this clear:

"The farsighted and enabling provisions of the $74^{\text {th }}$ Constitutional Amendment have not been fully embraced in Karnataka. As a result, Urban Local Bodies suffer from two kinds of shortfalls-one, they do not have the necessary financial strength or autonomy that is necessary to develop their capacity for municipal administration, and must therefore rely on State-level funding for their various programmes. Secondly, only a subset of the various responsibilities given to them under Constitution has been transferred by the State, and citizen's participation in governance of urban areas remains an unfulfilled promise (unlike rural areas, where Panchayati Raj institutions have greatly devolved power to local communities)." - Urban Development Policy for Karnataka (draft, 2009: pp.5)

"Under the Constitution, urban planning and town planning as also social and economic development and protection of the environment are functions to be performed by urban local bodies. However, in Karnataka, these responsibilities have not yet been assigned to the municipalities." - Urban Development Policy for Karnataka (draft, 2009: pp.36)

The quotations have been taken from a document available with the Urban Development Department, Bangalore, placed online in November 2009. Titled 'Urban Development Policy for Karnataka', the draft document deals with all the aspects of urban development in the state. Taking only two aspects from its recommendations, we observe that the policy document makes a strong case for "democratic local governance", besides suggesting "integrating spatial planning with economic development planning". It also recommends the repealing of certain Acts and giving more powers to legislators etc. It is also clear from the above quotations that the institutionalization of "democratic urban local governance" has not yet been fully implemented. Although the document was prepared in 2009 under the rule of the Bharatiya Janata Party (BJP) in the state, no policy emerged from the draft following the change of government.

However, it needs to be emphasized that at least in respect of Karnataka, a draft policy is in place. Whichever government is in power can modify, rework or change the document before implementing the same. All the same, there is a possibility of an affirmative action being taken. One even wonders how 
many states in India even have such a draft urban policy document prepared. However, since its recommendations have not been implemented, we cannot pass comments on the effectiveness of its policy prescriptions.

The state of urban governance in the case of Dharwad and Udupi partially exemplifies the quotations provided above. But governance is not just about policy documents, it is about people, citizens and the dwellers in these cities too. It is for this reason that the last question raised in the article that is, social capital, assumes significance as far as city governance is concerned.

\section{DISTRICT LEVEL CASE STUDIES FROM KARNATAKA}

\section{Dharwad}

Dharwad is a major educational and cultural centre of North Karnataka. Governed by the municipal corporation, it comprises the twin cities of Hubli (Hubballi) and Dharwad. Hubli is a commercial centre while Dharwad, a cultural and educational centre. The total population of Hubli-Dharwad constitutes around 13 lakh. The population of Dharwad alone comes to around 7 lakh. The city faces several major problems, which have been persisting over a long time. There is an acute shortage of drinking water with its supply being rationed. However, of late, some wards are accessing a 24/7 water supply on an experimental basis as part of a World Bank-supported drinking water project. The City is faced with severe shortage of drinking water in summer besides sanitation related problems. Governance of solid waste management and drainage systems is poor. ${ }^{4}$ There are 24 slums in Dharwad and providing civic services to them is a challenge. The city also often faces communal tensions mainly between the Hindu and Muslim communities ${ }^{5}$. However, it would be incorrect to isolate Dharwad from the rest of Northern Karnataka when it comes to examining the city's problems such as shortage of water as an individual case, since the overall backwardness is shared by the entire sub-region. Despite its rural background and governance problems, Dharwad is still a highly developed cultural and educational hub for the entire Northern Karnataka. However, the fact remains that governance is seriously lacking in this city much of which can be attributed to civic apathy. The activities of civil societies such as NGOs and voluntary agencies, and civic awareness are low as compared to Udupi. The city of course is much bigger than Udupi in terms of population and geographical spread, but civic activity in making governance work towards solving its persisting problems has been relatively low. This is despite the fact it has produced quite a few musical and intellectual geniuses, who are greatly appreciated not only in Karnataka, but also throughout the country.

A serious drawback noticed during the field work related to the inadequacy of city municipalityrevenues in addressing its civic problems. This is true of many district cities in Karnataka as well as larger cities facing acute financial problems. But given the educational, cultural and intellectual capital of the city $^{6}$, Dharwad could have performed better in respect of day-to-day governance. Its failures extend not only to the functioning of institutions, but also the civil society ${ }^{7}$.

Our field-based observations regarding the problems of the city of Dharwad clearly point to a lack of social capital in addressing the issues concerning day-to-day governance. This deficiency is more visible despite the city's achievements in the realm of culture. A major impetus to urban governance comes from a governance-institutions and local-civil society synergy, which raises the quality of urban governance. The effectiveness of citizenry is often inversely proportional to the city size, with resultant indifference and civic apathy ${ }^{8}$. However, there is no denying the contrast between Udupi and Dharwad as far as the influence of social capital on governance is concerned. In fact what appears apparently puzzling is that the governance related performance of Dharwad is not on par with Udupi with all its cultural and intellectual capital.

The Human Development Report of Dharwad-2014 presents the urban scenario of the city in the following words:

"The urban population in Dharwad has increased from 8.8 lakh in 2001 to 10.5 lakh in 2011 at a rate of 19 percent during the ten-year period. Rate of increase in urban 
population is slightly higher than the total population, which has increased by 15 percent. As a result, the percentage of population residing in urban areas has moved up slightly from 55 percent in 2001 to 57 percent in 2011."

There are six urban local governments in Dharwad district and the total urban population constitutes 57 percent. Of this, 90 percent lives in Hubli-Dharwad twin cities. Dharwad was the headquarters of the collectorate in the Bombay province and Hubli a Municipal borough of greater Bombay. When Karnataka was formed in 1956, the then rulers thought that these two should come together and in 1962, they were merged into Hubli-Dharwad Municipal Corporation. The-now merged entity is the second biggest and oldest corporation after Bangalore. Hubli is basically a commercial centre, while Dharwad an educational centre.

Many poets, musicians and classical Hindustani singers hail from Dharwad, which is also known as the 'pensionopolis', i.e., a place for retired persons. It is an ideal city for leading a quiet life. Recently, its population has increased due to a rapid rise in employment opportunities and the setting up of a high court branch. Of late, many from rural areas, especially people from nearby villages, have migrated to Dharwad in pursuit of education and employment.

Our field visits to Dharwad demonstrate that for a city of its size, municipal pourkarmikas (workers) are few in number and are also not efficient in solid waste management. They dump the waste on roadsides which in turn leads to the pollution of water and surrounding areas. The open drainage system is not maintained properly either. Although many NGOs are active in the health and education sectors, no one is making an effective intervention with respect to urban issues. The interviews inform us that with good cooperation and effective people's participation, governance can be improved. Although housing conditions are improving and many new buildings are coming up, agricultural land is being converted to residential purposes with many private companies now being engaged in the construction of new buildings.

We conducted interviews in Dharwad related to different aspects of city governance. What comes out clearly from these interviews is that Dharwad is essentially a cultural city known for higher education and accordingly the only observable urban changes are around these two aspects. But the basic problem is that Dharwad has not witnessed any change as far as public and other service deliverables is concerned. This apart, the roads are narrow, badly needing widening, and illegal constructions outside private properties are common, while the undulating landscape of the city does not allow scope for expanding the public road system. It also comes out that the increasing number of private vehicles in almost all the localities has almost reduced the open space available for ensuring safe transport. Known as the city of seven lakes, Dharwad has lost several open tanks due to urbanization. For instance, a popularly known tank called 'Yamikeri tank' has totally dried up. Although there have been several efforts made to de-silt the existing lakes recently, the programme lacks governance in terms of regulations, maintenance and creation of awareness regarding the lakes.

A 24/7 water supply scheme is being run on an experimental basis in Hubli-Dharwad twin cities, though with only two wards of Dharwad being covered presently. A study by Centre for MultiDisciplinary Development Research (CMDR), Dharwad on the functioning of the scheme, makes some references to the increasing cost and the difficulties involved in providing this facility to slum areas. The burden of increasing water rates seems to be coming in the way of an effective implementation. There is a general problem of water shortage in Hubli-Dharwad cities because of supply constraints associated with the Malaprabha river. An additional water supply from the proposed Kalasa-Banduri Nala diversion from Mahadai river is being examined by a Supreme Court-appointed tribunal. In the absence of an additional water supply, it may be difficult for these twin cities to implement $24 / 7$ water supply in all the wards in the near future.

\section{Governance of the City}

According to the respondents ${ }^{9}$ participating in the interview because of the expansion of a number of higher education and training institutions, there is an influx of young people into the city. The city, known 
for long as the habitat of seniors, the elderly and the retired, is now finding it difficult to reach out to the younger migrants and to encourage them to take an active part in its urban governance. It has also not received the due support of the public authorities for reasons such as non-availability of funds or nonresponse from the public at large. As a result, maintaining public parks and parking places for vehicles and enforcing road traffic rules are becoming increasingly difficult, a sign of increasing strain on governance. For instance, people are not even willing to pay property taxes or taxes on garbage collection.

On how governance can be improved, according to the residents, a proper implementation of legislations is required. It appears that smaller street- or locality-based community associations and organizations can make a positive impact provided they are trained and empowered regarding issues such as garbage handling and recycling, maintaining street lights, small libraries, public parks and lakes. Secondly, it also appears that there is a need for improving the communication between the residents and the public authorities concerned.

Some citizens think that it is also necessary for the authorities to hold meetings with the public regarding the city's cleanliness and that the city doesn't seem to have a concept of planning. If at all city planning is undertaken, it is mostly about restructuring the central part of the city to find space for educational institutions and residential areas. Solid waste disposal and open drainage system are the major governance problems facing Dharwad city. The respondents say that the problem of solid waste management has not received the attention it deserves from the public authorities. Also, managing drainages is very difficult in Dharwad in view of the undulating landscape. There are many reports of downstream colonies being troubled by excess drainage water and waste. Unless disposal and dispersal of drainage water are undertaken based on a scientific elevation of land, these will become a burden transferred to the downstream colonies at the cost of upstream colonies, who enjoy cleaner habitats. There is also an urgent need for building an underground drainage system in the market areas of the city.

Although there is some improvement in drinking water supply, sanitation issues remain unresolved in Dharwad with the civic bodies struggling to provide water and sanitation to all the wards. The slums and the poor are among the worst affected. An Increased water supply with no sanitation facilities can further worsen the situation in the urban slums. The HDI Report brings out these problems quite clearly:

"The worsening urban poverty and concomitant deprivations are the other issues that are becoming serious day by day. Provision of drinking water, sanitation, solid waste management and poverty are the major urban problems that have implications for HDI of urban residents." --Dharwad District Human Development Report 2014(pp.255)

Dharwad District Human Development Report 2014 goes on to add that the percentage of slums has a positive co-relation with the size of the urban local governments, and the population residing in the slums comes from the most marginalized sections such as Scheduled Castes( SCs) and Scheduled Tribes(STs).

Ensuring a clean drinking water supply and sanitation facilities is the duty of urban local governments, and they have to make sure that all citizens get these basic rights. These services are not to be sold for profit. The need for urban governance is likely to go up because increasing urbanization will bring in more and more poor into the urban areas.

Dharwad city planning and governance are still with the DC's office and the municipal commissioner's office. The role of legislators in the city's governance is unclear with bureaucracy calling all the shots. We have already discussed at some length the drinking water situation in Dharwad. The World Bank-implemented 24/7 water project has not yet been fully extended to all the wards in the city, leaving aside the drawback of higher water charges and their collection. Our field observations reveal that sanitation facilities in Dharwad city have improved in the past two years.

The more important problem, however, relates to social capital. For one, Dharwad comes under the municipal corporation of the twin-city Hubli-Dharwad, and together with Hubli, it is much bigger than Udupi. The size of the city makes it difficult to manage. There also exist ethnic divisions in the city, with 
communalism spreading. There were glaring incidents reported of the breakdown of law and order because of inter-ethnic tensions in the recent past in the city.

\section{Udupi}

The Udupi district Human Development Report, 2008 provides an introduction to the district in the following words:

"Udupi is one of the twenty-seven districts in Karnataka state. It was formed on $24^{\text {th }}$ August 1997, carved out of the erstwhile Dakshina Kannada (South Canara) district with three blocks, namely Udupi, Karkala and Kundapura. Udupi city is the district headquarters. Historically, it was part of Vijaynagar kingdom and subsequently under Mysore rule. During the British rule, it came under Madras Presidency. With the formation of linguistic states in 1956, it got merged with Karnataka state. Along with Dakshina Kannada, it is commonly known as 'Tulu Nadu."

Udupi is a coastal temple-city in southern Karnataka, with a total population of $1,35,000$. It is a district city governed by the $74^{\text {th }}$ Amendment to the Constitution. The city is remarkably well governed, with underground drainage and sanitation and surplus drinking water facilities. The city municipality functions effectively with basic civic services such as drinking water and sanitation being taken care of effectively. The city council is elected periodically and follows the provisions of the Constitution strictly. Any visit to the city leaves us with a striking impression of its cleanliness and well-organized and wellfunctioning urban governance. What makes governance work in Udupi? The city is well governed in view of an active and informed citizenry. An active and vocal civil society ${ }^{10}$ keeps the municipality accountable $^{11}$. Different civil society organizations like Citizens Consumers' Forum (CCF) conduct regular interactive meetings between citizens and municipality. The other specific feature of Udupi is that the two main political parties in the city, the Indian National Congress (INC) and the Bharatiya Janata Party (BJP) and their leaders, not only win elections periodically but take an active interest in the affairs of the municipality, irrespective of their political/ ideological predelictions ${ }^{12}$. The city has resource persons on the $74^{\text {th }}$ Amendment and its implementation in Karnataka, whose services are also utilized by the State Institute of Urban Development (SIUD), Mysore. The municipal bureaucracy too is accountable to both the political parties and citizens ${ }^{13}$. According to the $74^{\text {th }}$ Amendment of the Constitution, the District Planning Committee of the district has to conduct urban and rural integrated planning. But throughout Karnataka, as elsewhere in India, a small cell in the DC's office is in charge of urban planning. The same is the case with Udupi ${ }^{14}$. The difference, however, is that rural plans are prepared by the District Planning Committees (DPC) and the elected Zilla Panchyat (ZP) in all the districts in Karnataka. The function of urban planning alone does not distinguish Udupi from other district-level urban cities in the State ${ }^{15}$. What distinguishes it from other cities is the social capital between political parties that manage the city, a municipality that is ready to cooperate and the active civil society and citizens' forums that hold the municipality and political parties accountable ${ }^{16}$. The concept of 'governance', in its simplest definition, means a 'pattern of rule'; and the current usage and definition of governance mean bringing non-governmental agencies, either private market institutions or civil society agencies, into the pattern of rule (Bevir, 2011). This is meant to enhance the effectiveness of the rule. However, effectiveness requires trust, norms and reciprocity between different actors. That precisely is social capital, which appears to be relatively more visible in Udupi, and which is why governance is more effective than in Dharwad, where it appears to be less effective.

There is a well-functioning Zilla Panchayat (ZP) Office in Udupi, which prepares the rural plans. But the urban/city planning is done entirely by the municipality. The remarkable aspect is that the municipal council makes the city municipality work very efficiently. The municipal office is accountable to the municipal council. As our interviews show, the municipality keeps the streets exceptionally clean - for a district city in India - and there is no drinking water supply problem. The only civic service that is not in perfect condition is the drainage, as the city does not have a 100 percent underground drainage system. 
Much like in other districts in Karnataka, the integration of urban plans into rural plans, by Zilla Parishad (ZP), is a problem in Udupi too with the municipality and the urban cell in the District collector's office calling all the shots.

How is the city governance? It is remarkably effective and efficient in thanks to a synergy between the citizens of Udupi and the city municipal council. There is also a remarkable social capital present among the citizens of Udupi, irrespective of their political affiliations. Both INC and BJP come together and exert pressure on the municipal council to work for an effective delivery of civic services with sanitation as a case in point. The city also has well-functioning public libraries. It is remarkable that even the hoteliers' association takes a keen interest in the upkeep and sanitation and civic services of the city. Hence it is no surprise that the city's governance works effectively.

The city has slums in adjacent Manipal inhabited by migrant workers, from Hyderabad-Karnataka and other parts of the country. They also seem to be satisfied with the basic civic services such as drinking water and sanitation being provided to them. It is also worth noting that Municipal councilors do attend to their problems

The major advantage of the city lies in the civic culture of its citizens and the manageable size of the city unlike the other cities under consideration here.

\section{URBAN GOVERNANCE POLICY IN TELANGANA: CONTINUED NEGLECT}

There is no clear urban governance policy put forth for cities of Telangana. Although there exists a great amount of enthusiasm and drive towards developing the cities, it is yet to be translated into a coherent policy. Therefore, the question of implementation of policy does not arise here. What we have instead are steps towards the revitalization of the municipal administration, being undertaken by individual bureaucrats on their own in some districts. The same can be said in respect of district planning and District Planning Committees (DPCs). District planning and DPCs have long been neglected under the long rule of Telugu Desam Party and later under the INC. These DPCs have now been reinvented by the current Telangana Rashtra Samiti (TRS) government. Although elections to the local bodies have been held in all cities, municipal councils and corporations, there is no single explicit document prepared regarding governance policy for all. The same is the situation in our study city of Mahabubnagar in Telangana. In this city, and many other district-cities in this state, the private sector is making major inroads, linking the markets to metropolises and even to global markets. But there is no attempt made to regulate this growth and to plan for it at the local level. Telangana is a fast-growing state, and the sooner the newly formed government develops a policy for its cities, the better it will be for their burgeoning population.

In addition to natural growth, cities in Telangana also share a migrant population from villages in search of work, education and livelihood. These cities have to accommodate the migrants while coping with its original population at the same time. Although there is no (Information Technology) IT sector in the districts as yet, going by the announcement of IT policies by the Telangana government, one can assume that in future, the sector will reach to the district-cities too, at least some of them. This can create a huge demand for infrastructure, urban civic amenities and basic services. A policy enunciating a future perspective for Telangana district cities is yet to be developed. Therefore, at present they are facing the same neglect as they did under the previous dispensations.

Therefore, we can term the situation of Telangana cities as one of continued neglect. Not just the government, even among the academia, media, civil society and intellectuals, there is a general lack of discussion concerning the future scenarios facing the cities. This is even more problematic than before. Given the current context, the new government should, with all its power and imagination at its disposal, be able to refashion the governance of Telangana's cities, which are growing now mainly on the lines of private sector rather haphazardly. Increasing reliance on ad hoc measures to solve the problems of cities may not prove effective in the long run. 
This dire situation is more discernible in our study district of Mahabubnagar, which is about 140 kilometers or a two-hour drive from Hyderabad. It shares many aspects of Telangana cities, which we have described above.

\section{District Level Case Study From Telangana Mahabubnagar}

Mahabubnagar ${ }^{17}$ consists of 41 wards, with 38.99 percent of the city, or 74,244 of its population, living in slums. There are a total of 12 Urban Local Bodies (ULBs) in Mahabubnagar district. There are 87 notified slums in Mahabubnagar city; the others are not. Although elections were conducted for all the ULBs, the ward committee GO has not yet been implemented in this city. The ULBs as well as all municipalities are financially self-sufficient. They have received $13^{\text {th }}$ and $14^{\text {th }}$ Finance Commission grants, and other grants from the state government. Additional taxes and resources can be mobilized, given there exists is a great potential for mobilizing resources for the municipality. When all these are done, this municipality will be in surplus. Already it has a surplus budget. There is certainly no shortage of funds.

Coming to drinking water supply, the municipal officials inform us that earlier, the municipality used to supply water once in 4 to 5 days; now they are supplying every 3 to 4 days. This includes Salt water for bathing, washing etc. being provided every day. The municipality is providing Krishna water for drinking needs. For this, the charges collected amount to Rs. 100 per month. There is no metering of drinking water usage. It is a flat rate per household.

Regarding sanitation, as the municipal commissioner observes, it has definitely improved in the last one year. Earlier, the sanitation workers were working only on a single shift during the forenoon, now they are working on two shifts from 5.30 am to $10.30 \mathrm{am}$ and from 2:00 pm to 5:00 pm. There are also no problems as far as the disposal of solid waste or garbage is concerned. The municipality has 25 acres of wasteland at its disposal, where garbage is dumped. Currently there are 425 sanitation workers with the municipality. Of these, 143 are permanent workers. The others work on contract basis or are outsourced. The majority are outsourced. The total required number of sanitation workers is 522 .

The plans for ULBs are prepared by municipalities and are submitted to Directorate of Town and Country Planning (DTCP). The ULBs come under the Municipal Administration and Urban Development Department of the State Government. It is not the district collector's office which prepares plans. Municipal bodies themselves prepare urban plans. These are then submitted to the DTCP directly. The current growth of the city is neither haphazard nor planned. It is happening in an ad-hoc manner. Private layouts and buildings are developed first before being regularized later. At the sub-district level of urban bodies, there is not much planning taking place.

\section{The Problems Facing the City ${ }^{18}$}

The informants of the city hold that change in Mahabubnagar city happens slowly. The city is faced with the problem of outmigration. Many youths migrate to Hyderabad and other places seeking jobs and education. From rural areas, people migrate to Mumbai. There is always a 'Mumbai bus' to take the migrants to their destination. Migration is seasonal in rural areas and permanent in urban areas. Those who migrate rarely come back to town.

It is obvious from our visits to the city that the infrastructure base is very poor, with the roads being very narrow. Once, a strict commissioner wanted to remove all the commercial hoardings for widening the roads, but he could not succeed because of strong political pressure. Business people put pressure on him through political leaders not to remove or change the hoardings in the city.

Also discussions with respondents show that the city is now dominated by the regional party, Telangana Rashtra Samiti (TRS), with the INC and BJP being the other players in the political arena. Earlier, Congress had ruled the city for a long time. The city's population comprises 60 percent of Hindus and 40 percent of Muslims with communal tensions erupting frequently, mostly on occasions such as Ganesh Chaturthi (the local Hindu festival) and during times when religious processions are taken out. 
Being close to Hyderabad, there is also a 'Hyderabad effect'. Whatever happens in Hyderabad finds its echo in Mahabubnagar, including communal tensions.

But it comes out from our field observations that, overall, there is a communal harmony. The Hindus go to Abdul Khader Darga (a Muslim religious place), while Muslims take part in the Ganesh Chathurthi procession. Urs, which is a Muslim religious festival, draws a large number of Hindus too. On the whole, this is the situation that prevails. But tensions break out when outsiders or political parties deliberately play the communal card whipping up religious differences for various reasons.

City transport is entirely managed by autos, which ply in thousands. With demand for road transport being very high, and the number of vehicles including cars has increased manifold.

In the city, drinking water is scarce with the municipality supplying once in six days. In summer, the municipal office supplies water through tankers, but that is not sufficient for the season. At the same time, there are many water purifying plants (reverse osmosis) in the city that make hard water potable and these plants are doing a brisk business. The entire district has been affected by drought and water scarcity, and so is the city.

So far as drainage is concerned, new colonies have access to underground drainage system but old colonies have access only to an open drainage system, which is prevalent in 80 percent of the city, and only 20 percent of the people have access to an underground drainage facility.

\section{DISCUSSION}

We began this paper with four questions, namely: a) how is the district-city planning taking place?; b) how efficient/ effective is the delivery of basic services such as drinking water and sanitation?; c) how effective is the city governance?; d) lastly, are there any social capital issues that merit attention? It comes out clearly from the forgoing analysis that planning of district-level cities both in Karnataka and Telangana is not taking place according to the constitutional stipulations. Deputy Commissioner's office in Karnataka and Municipal Commissioner's office in Telangana determine all the urban planning matters concerning the respective districts. In addition, we have seen that DPCs as democratic planning institutions exist in Karnataka but remain dysfunctional, whereas, in Telangana, DPCs do not even exist.

Secondly, the delivery of basic services such as drinking water, sanitation and solid waste management leaves much to be desired in respect of all the three cities. All the three cities suffer from open drainage problem and often in most of the localities in the cities do not have access to an underground drainage system, which in turn leads to many sanitation related problems. In addition to this, the solid waste management is a huge problem in Dharwad and Mahabubnagar but the status of drainage and solid waste management is much better in the case of Udupi which could be attributed to a better social capital amongst citizens.

Thirdly, if we were to gauge the effectiveness of governance of the cities-- by the standard of meeting basic needs of drinking water and sanitation of all the citizens-- all the three cities are found wanting in this respect, Udupi as the only exception. Udupi is an exception to the rule in our sample, because it is a smaller city with a better cooperation prevailing among the citizens which in turn helps to run the basic services efficiently. The exceptional nature of governance can be explained in terms of a) Udupi is a smaller city and therefore more easy to govern from above; b) Udupi is a Temple-city wherein special interest is taken in matters of sanitation and drinking water by the citizens as well as the Municipality; d) Udupi belongs to Southern part of Karnataka wherein the region is contiguous with Kerala and the culture of public action and citizen action that is to be found in Kerala is also found in Udupi. However, this is not the case with Dharwad wherein the civic culture is not the same that of civic and public action. It is also to be noted the within Karnataka the entire southern Karnataka has higher HDI ranking status than the northern Karnataka. Consequent to all these facts is that there is better civic cooperation among the citizens of Udupi in making municipality deliver the public goods of drinking water and sanitation. This is not at all the case with Dharwad and Mahabubnagar.

Lastly, but not the least, the social capital is low in both Dharwad and Mahabubnagar. This comes out from the interviews we conducted as well as from the fact that both the cities remain affected by 
communalism. We have explicitly and clearly discussed the communal situation in Mahabubnagar. In respect of Dharwad also we have indicated the abysmal failure of law and order at times owing to communalism. In the case of Udupi we have pointed out that although Udupi city per se may not be witnessing serious communal tensions, it is surrounded by Mangalore region which has serious communal conflicts taking place frequently.

\section{CONCLUSION}

It comes out quite clearly that the $74^{\text {th }}$ Amendment to the Constitution is neither implemented in letter nor in spirit when it comes to district level cities. The three cities discussed here are representative of the cities all over the country. The problems we witnessed in these cities are lack of regular drinking water, lack of proper sanitation and drainage systems, inadequate solid-waste management systems etc. and what is more problematic is that often there is no sufficient social capital to address these issues at the local level. The implementation of Constitutional governance, even at this level, requires pressure to be put on the governance. Only then will the institutions function and deliver. We found the social capital to make city governance function missing in two of the three sample cities. The city in the sample where we found remarkable social capital, so far as urban- local governance is concerned, is Udupi. However such cities appear to be more exceptions in the country than the rule. What is more important is for social capital to address the fast spreading communalism in cities at this level. This is even more alarming condition. To conclude, better social capital at the level of district level cities, to make the local governance, and the concerned authorities, function effectively and to safeguard the social fabric from becoming communalized is the need of the hour.

\section{ACKNOWLEDGEMENT}

Earlier version of the article was published in the Journal Urban India. The details of which are as follow: Anil Kumar Vaddiraju, 'District Level Urban Governance Policies in India: Cities of Neglect?', Urban India, Vol: 39, No :1, pp. 134-142. Copyright (C) 2019, NIUA. Reprinted by permission of NIUA.

I thank ISEC for the funding for this study through the research project CPIGD-48. I thank G. Aruna for her Research Assistance during the study. I am indebted to the following people for their helpful comments on the paper. Kala Seetharam Sridhar, N.Sivanna, C.M.Lakshmana, S. Manasi, M.V.Nadkarni. Special thanks to Gopal Kadekodi, the respective faculty members at CMDR, Dharwad; and Palamoor University in Mahabubnagar. Thanks are due to the anonymous referees for their enormously helpful comments. All limitations of the paper are author's own. This paper is dedicated to all the classical musicians of Dharwad city, past and present

\section{ENDNOTES}

1. In this paper we have selected the states Karnataka and Telangana purposively. This is because Karnataka and Telangana are contiguous states, have linguistic and socio-cultural similarities; finally the extent of urbanisation in both the states is similar. Thus, both the states share many similarities and some differences. That is why both these states were selected for comparison. These two states have high commensurability. And also this paper is not based on secondary research. The research for this paper involved multiple primary visits to the cities discussed herein.

2. We have chosen Udupi and Dharwad cities for comparison for two reasons: a) Udupi city falls in the southern Karnataka region while Dharwad is in the northern region of Karnataka, and b) Because in our interviews with officials in the State Institute of Urban Development (SIUD), they mentioned that Udupi and Dharwad are relatively better governed cities compared to others. The selection of Mahabubnagar city in Telangana is for logistical purposes. Besides, there is no institution comparable to Karnataka's SIUD in 
Telangana. Therefore, there is no source for us to identify which cities are relatively better governed in Telangana.

3. This data was collected in an interaction with the officials of State Institute of Urban Development (SIUD), Mysore.

4. When field work was conducted, Gopal Kadekodi, a resident of the city, stated: "The basic problem which I see is, not seeing any change in terms of public and other deliverables. There has not been any major breakthrough in drinking water supply or in drainage management. In terms of the impact on people, the effect has been increasing health problems which are linked to water, open drainage system and nondisposal of solid waste."

5. For instance, K. Raghavendra Rao, a noted political scientist in Karnataka and resident of Dharwad, has this to say about the situation of the society and community in Dharwad: "What is the use of giving power to people, when there is no exercise of power; until and unless the government is ready (and sets out to govern), one cannot govern them. Caste is very vibrant and politically active in Dharwad. Lingayats are a commanding community in terms of education, literacy, economy and culture, and of course Dalits are large in number but they lack resources. Communalism is present, is very strong and stands as an important element in the political system."

6. We conducted interviews (from April 23rd 2014 to 26th 2014) with scholars in Karnatak University, Centre for Multi-Disciplinary Development Research, municipal and planning officials and with local observers and with journalists who have been living in the city for a long time. The names are too numerous to mention here. They all agree on the basic problems of the city, while mentioning its cultural and intellectual significance.

7. Harish Ramaswamy, who teaches in Karnataka University, Dharwad makes this point: 'Now look at the infrastructure growth. It is terribly backward. Why? People never demand anything... social networking is terribly bad and we also see that social capital is very weak (and) even now they don't come together, they don't mix together, they don't demand and ask for anything nor do they state anything." This observation sums up the point we are trying to elaborate.

8. Civic apathy in urban areas regarding urban governance and governance in general is surprising. Urban areas usually have higher literacy rates than rural areas, e.g., around 80 percent in India, but the voting percentages are lower, as also civic participation, while civic apathy is more. Why is this so? Does it have to do with the type of education and literacy or the kind of society that exists in urban areas generally, with its impersonality and individualism? We can only wonder at this phenomenon.

9. The respondents with who the interviews were conducted were mostly selected by snowball sampling method. They are prominent academics, scholars who have worked on urban issues of Dharwad and long time residents of the Dharwad city. These included the scholars from Karnatak University Dharwad, scholars from CMDR Dharwad and other prominent observers of the city including local journalists and retired academics. We did not conduct a structured quantitative sample survey. The views reported are based on qualitative interviews based on unstructured list of questions organised around the central themes of the paper.

10. Human Development Report of Udupi, 2008, mentions in particular the civil society organisations in Udupi District: "Udupi District is blessed with a large number of NGOs and voluntary agencies actively involved in human development initiatives." In this article, however, we concentrate on urban governance, but the fact is that civil society is active in this district.

11. Interview with K. Damodar Aital, Convenor of CCF (Citizens' Consumers Forum) in Udupi,

12. Interview with Gujjadi Prabhkar Naik, BJP leader in Udupi.

13. Interview with municipal officials, Udupi.

14. Interview with Vijay Kumar Shetty, Chief Planning Officer, Zilla Panchayat Udupi.

15. Interview with Mr. Ramakrishna in Deputy Commissioner's office, Udupi.

16. Interview with Gujjadi Prabhakar Naik, BJP leader in Udupi. The interviews with Indian National Congress leaders and the current municipal commissioner too corroborate this. Both the political parties acknowledge 
the role of civic groups in the governance of the city and the current Congress Party leadership does acknowledge the role of the opposition party in city governance. For example, during interviews with Manjunath Iyer, Municipal Commissioner, Shri P. Yuvaraj, the current President of Udupi City Municipal Council from Congress Party and other Congress leaders, Vijayjathan Manchi, Standing Committee President, Udupi Municipal Corporation and PA to the local MLA Mr. Promod Madhuaraj, the Chief Environmental Engineer of the municipal corporation, they all accept the role of civic groups and the combined role of different political parties in making the city governance effective.

17. This part of the article is based on the interview with Mr Bhukya Dev Singh, Municipal Commissioner, Mahabubnagar city on 16th February 2016 at Mahabubnagar.

18. This part of the article is based on the interview with Dr. Arjun Kumar, Assistant Professor, Department of Business Management, Palamoor University, Mahabubnagar, Telangana, on 17th February, 2016. He has also been a resident of the city of Mahabubnagar for the past 35 years.

\section{REFERENCES}

Anil Kumar, V (2013). Urban Governance and Planning in Karnataka. In R.N. Sharma \& R.S. Sandhu (Eds.), Small Cities and Towns in Global Era: Emerging Changes and Perspectives (pp. 318330). Jaipur: Rawat Publications.

Bevir, M. (2011). Governance as Theory, Practice and Dilemmas. In M. Bevir (Ed.), The SAGE Handbook of Governance (pp. 1-16). London: SAGE.

Bevir, M. (Ed.). (2011). The SAGE Handbook of Governance. London: SAGE.

CESS. (2016). Telangana Human Development Report: District Profiles. Hyderabad: Centre for Economic and Social Studies.

Davies, J. S., \& Imboscio, D. L. (Eds.). (2009). Theories of Urban Politics. Los Angeles and London: Sage Publications.

Gill, R. (2013). The Academic Bias against Towns: A Cultural Audit. In R.N. Sharma \& R.S. Sandhu (Eds.), Small Cities and Towns in Global Era: Emerging Changes and Perspectives (pp. 84-98). Jaipur: Rawat Publications.

Government of Karnataka and Zilla Panchayat, Dharwad. (2015). Dharwad District Human Development Report, 2014. Bengaluru: Planning, Programme Monitoring and Statistics Department.

Government of Karnataka. (2008). Human Development Report of Udupi. Bangalore: GOK.

Jenkins, R. (2004). Regional Reflections: Comparing Politics Across India's States. New Delhi: Oxford University Press.

Jha, S. N., \& Mathur, P. C. (1999). Decentralisation and Local Politics. New Delhi: Sage.

Kundu, A. (2003, July 19). Urbanisation and Urban Governance: Search for a Perspective Beyond NeoLiberalism. Economic \& Political Weekly, pp. 3079-87.

Kundu, A. (2006). Globalization and the Emerging Urban Structure: Regional Inequality and Population Mobility. In India: Social Development Report (pp. 110-124). New Delhi: OUP and Council for Social Development.

Kundu, D. (2006). Globalization, Decentralization and Crisis in Urban Governance: Providing Drinking Water and Sanitation Facilities. In India: Social Development Report (pp. 50-64). New Delhi: OUP and Council for Social Development.

Paul, S., Sridhar, K. S., Reddy, A. V., \& Srinath, P. (2012). The State of Our Cities: Evidence from Karnataka. New Delhi: OUP.

Sharma, R. N. (2013). "Citiness" and "Urbanity": The Privilege of Megacities. In R.N. Sharma \& R.S. Sandhu (Eds.), Small Cities and Towns in Global Era: Emerging Changes and Perspectives (pp. 54-70). Jaipur: Rawat Publications.

Shaw, A. (2013). Emerging Perspectives on Small Cities and Towns. In R.N. Sharma \& R.S. Sandhu (Eds.), Small Cities and Towns in Global Era: Emerging Changes and Perspectives (pp. 36-54). Jaipur: Rawat Publications. 
Swain, B. (2013). Small Towns, their Limited Resourcing Options and Equity Deficits. In R.N. Sharma \& R.S. Sandhu (Eds.), Small Cities and Towns in Global Era: Emerging Changes and Perspectives (pp. 98-111). Jaipur: Rawat Publications.

Tawa Lama-Rewal, S. (2011). Urban Governance: How Democratic? In M-H. Zerah, V. Dupont, S. Tawa Lama Rewal (Ed.), Urban Policies and the Right to the City in India: Rights, Responsibilities and Citizenship (pp. 21-31). New Delhi: Centre for Human Sciences and UNESCO.

Urban Development Department, (Draft). (2009). Urban Development Policy for Karnataka. Bangalore: Urban Development Department.

Zerah, M-H., Dupont, V., \& Tawa Lama Rewal, S. (Ed.). (2011). Urban Policies and the Right to the City in India: Rights, Responsibilities and Citizenship. New Delhi: Centre for Human Sciences and UNESCO. 